\title{
Identification of avian $\alpha$-melanocyte-stimulating hormone in the eye: temporal and spatial regulation of expression in the developing chicken
}

\author{
K Teshigawara, S Takahashi, T Boswell ${ }^{1}$, Q Li $^{1}$, S Tanaka ${ }^{2}$ \\ and $\mathbf{S}$ Takeuchi \\ Department of Biology, Faculty of Science, Okayama University, Okayama 700-8530, Japan \\ ${ }^{1}$ Roslin Institute (Edinburgh), Roslin, Midlothian EH25 9PS, UK \\ ${ }^{2}$ Department of Biology, Faculty of Science, Shizuoka University, Shizuoka 422-8529, Japan \\ (Requests for offprints should be addressed to S Takeuchi, Department of Biology, Faculty of Science, Okayama University, 3-1-1, Tsushimanaka, \\ Okayama 700-8530, Japan; Email: stakeuch@cc.okayama-u.ac.jp)
}

\begin{abstract}
The presence and possible physiological roles of $\alpha$-melanocyte-stimulating hormone $(\alpha-\mathrm{MSH})$ in the peripheral tissues of birds have not been established. By a combination of RT-PCR, immunocytochemistry and in situ hybridization, we have examined $\alpha-\mathrm{MSH}$ expression in the eye of the chicken during development. In the 1 -day-old chick, $\alpha-\mathrm{MSH}$ was expressed in the retinal pigment epithelial (RPE) cells, and also at a lower level in the cone cells. The melanocortin receptor subtypes, CMC1, CMC4 and CMC5, were expressed in the layers of the choroid and the neural retina, but not in the RPE cells. It is probable that the RPE cells secrete $\alpha-\mathrm{MSH}$ to exert paracrine effects on the choroid and neural retina. During embryonic development, $\alpha-\mathrm{MSH}$ immunoreactivity in the RPE cells was initially detected at embryonic day 10, and increased in intensity as develop-
\end{abstract}

ment proceeded. No cone cells were stained with anti- $\alpha-$ $\mathrm{MSH}$ antiserum in any of the embryonic stages tested. The immunoreactivities for two prohormone convertases, PC1 and PC2, were co-localized to the RPE cells with a pattern of staining similar to that of $\alpha-\mathrm{MSH}$. Despite containing $\alpha-\mathrm{MSH}$ immunoreactivity, the RPE cells in 1-day-old chicks expressed no immunoreactivity for the endoproteases. Furthermore, in a 3-day-old chick, proopiomelanocortin mRNA was detectable by in situ hybridization only in the photoreceptor layer and not in the RPE cells. These results suggest that the RPE cells and the cone cells are intraocular sources of $\alpha-\mathrm{MSH}$ in the embryonic and postnatal life of the chicken respectively. Embryonic expression of $\alpha-\mathrm{MSH}$ in the RPE cells implies a possible role for the peptide in ocular development.

Journal of Endocrinology (2001) 168, 527-537

\section{Introduction}

$\alpha$-Melanocyte-stimulating hormone $(\alpha-\mathrm{MSH})$ is a melanocortin peptide generated from the precursor glycoprotein pro-opiomelanocortin (POMC). The best known source of POMC in most vertebrates is the anterior and intermediate lobes of the pituitary. A series of ordered proteolytic cleavages of POMC with cell type-specific patterns leads to a cell type-specific mixture of melanocortin peptides displaying a wide array of biological effects (Eberle 1988, Smith \& Funder 1988, Mains \& Eipper 1990). Two kinds of endoprotease involved in this process have been well characterized; prohormone convertase 1 (PC1; also called PC3) generates adrenocorticotropic hormone (ACTH) from POMC, and prohormone convertase 2 (PC2) cleaves ACTH to produce $\alpha-\mathrm{MSH}$ (Benjannet et al. 1991, Korner et al. 1991, Thomas et al. 1991). Restricted expression of PC2 in the intermediate lobe identifies this part of the pituitary as a secretary gland for $\alpha-\mathrm{MSH}$.

In mammals, $\alpha-\mathrm{MSH}$ is now recognized to be widely expressed throughout the body and it has a broad array of physiological actions both in the central nervous system and in the peripheral tissues; this correlates well with its localization and that of its receptors, the melanocortin receptors (MC-Rs) (Eberle 1988, Cone et al. 1996). Two recently identified endogenous antagonists of MC-Rs, agouti protein (Bultman et al. 1992, Kwon et al. 1994, $\mathrm{Lu}$ et al. 1994, Wilson et al. 1995) and agouti-related protein (AGRP) (Ollmann et al. 1997, Shutter et al. 1997), act in a paracrine manner to regulate MC-R function. However, while the molecular mechanisms of $\alpha-\mathrm{MSH}$ actions in mammals are well understood, little is known about the biological activities of $\alpha-\mathrm{MSH}$ in birds. The physiological significance of avian $\alpha-\mathrm{MSH}$ remains uncertain as the pituitary gland of birds does not possess a 
distinct intermediate lobe of the pituitary, the main source of circulating $\alpha-\mathrm{MSH}$ in most vertebrates.

We have recently cloned all five receptor genes belonging to the MC-R family in birds, CMC1 (Takeuchi et al. 1996a), CMC2 (Takeuchi et al. 1998), CMC3 (Takeuchi \& Takahashi 1999), CMC4 and CMC5 (Takeuchi \& Takahashi 1998); these are chicken homologs of mammalian MC1 (MSH)-R, MC2 (ACTH)-R, MC3-R, MC4-R and MC5-R respectively. CMC1 is implicated in melanogenesis within melanocytes since it has been mapped at the genetic locus which acts to control feather color pigmentation in the chicken (Takeuchi et al. 1996b). CMC2 has been suggested to regulate steroidogenesis in the adrenal gland and immune functions in the spleen based on its distribution of expression (Takeuchi et al. 1998). Although no function has yet been ascribed to the other subtypes of MC-R in any tissues of the chicken, CMC5 shows a wide distribution of expression as in mammals (Takeuchi \& Takahashi 1998), while homologs of the mammalian central MC-Rs, CMC3 and CMC4, display different tissue distributions from mammals. Thus, CMC3 is expressed exclusively in the adrenal gland (Takeuchi \& Takahashi 1999) and CMC4 in a wide variety of peripheral tissues as well as in the brain (Takeuchi \& Takahashi 1998). Since most of those MC-R-expressing tissues have been found to express the POMC gene, we have hypothesized that avian melanocortin peptides, including $\alpha-\mathrm{MSH}$, serve as local mediators acting in a paracrine and/or autocrine manner to affect a variety of functions in both the brain and peripheral tissues (Takeuchi et al. 1999). Furthermore, analyses of the chicken genome as well as of distribution of the expression of AGRP mRNA have suggested the possibility that AGRP could be the sole endogenous antagonist of $\mathrm{MC}-\mathrm{Rs}$ involved in the regulation of MC-R signalings in numerous peripheral tissues in the chicken (Takeuchi et al. 2000). In contrast, nothing is known about the MC-R agonist, $\alpha-\mathrm{MSH}$, in terms of its localization and possible physiological role in peripheral tissues of the chicken.

Many lines of evidence have shown that administration of $\alpha$-MSH affects numerous functions of the eye in amphibia (frog) and mammals including humans, such as acceleration of the regeneration of visual purple (Hanaoka 1951, 1953), stimulation of the release of dopamine or $\gamma$-aminobutyric acid from the retina (Bauer \& Ehinger 1980, Bauer et al. 1980), increase of the permeability of the blood-aqueous barrier (Dyster-Aas \& Krakau 1964, Dyster-Aas et al. 1970), and stimulation of the production of eicosanoids in the retinal pigment epithelial (RPE) cells (Ilan et al. 1992). The source of the $\alpha-\mathrm{MSH}$ that acts in the eye remains unclear, for there is no correlation between circulating $\alpha-\mathrm{MSH}$ levels and the eye responses (DysterAas et al. 1970). Drager et al. (1983) have detected $\alpha-\mathrm{MSH}$ immunoreactivity in the eyes of chickens and a variety of mammals. However, this immunoreactivity has been ascribed to the expression of an $\alpha-\mathrm{MSH}$-like epitope by neurofilaments because the immunostaining was eliminated by preabsorption of the $\alpha-\mathrm{MSH}$ antibodies with the neurofilaments. However, it is still possible that $\alpha-\mathrm{MSH}$ is expressed within the eye at a level below the immunocytochemical detection limit, and/or that it undergoes temporal changes in expression during development.

The aim of the present study was to test our hypothesis that $\alpha-\mathrm{MSH}$ exerts paracrine/autocrine effects in peripheral tissues by determining whether $\alpha-\mathrm{MSH}$ is expressed within the chicken eye. By a combination of immunocytochemistry, RT-PCR and in situ hybridization, we demonstrate here for the first time that $\alpha-\mathrm{MSH}$ is expressed within the chicken eye, and that its expression during embryonic development is temporally and spatially regulated. The results suggest a novel role for $\alpha-\mathrm{MSH}$ in the embryonic development of the chicken eye and support our hypothesis that avian $\alpha-\mathrm{MSH}$ is a paracrine/ autocrine hormone (Takeuchi et al. 1999, 2000).

\section{Materials and Methods}

\section{Animals}

Tissues for RNA extraction, immunocytochemistry and cell culture were obtained from 1-day-old Rock Cornish chicks and/or embryos (embryonic day 7, 10, 13 and 17) purchased from a commercial grower (Fukuda Poultry Breeding Farm, Okayama, Japan). For in situ hybridization, tissue samples were taken from a 3-day-old female chick of the J-line strain of Brown Leghorns (Roslin Institute flock).

\section{Isolation of eye layers}

One-day-old Rock Cornish chicks were killed by cervical dislocation. The eyes were then rapidly dissected and placed in $\mathrm{Ca}^{2+}$ - and $\mathrm{Mg}^{2+}$-free Hanks' solution containing $20 \mathrm{mM}$ Hepes and $0 \cdot 3 \%$ bovine serum albumin (BSA; fraction V; Sigma, St Louis, MO, USA) (CMF-HSHBSA). An incision was made slightly posterior to the corneal limbus, and the anterior sections, lens and vitreous humor were then removed. The remaining posterior cup was divided into three to four pieces and placed in $0.5 \mathrm{mM}$ EDTA in CMF-HSH-BSA at $4{ }^{\circ} \mathrm{C}$ for $30 \mathrm{~min}$, and subsequently at $37^{\circ} \mathrm{C}$ for $40 \mathrm{~min}$. The tissue was washed twice with CMF-HSH-BSA. The layers of the $\mathrm{RPE}$, the neural retina and the choroid were membranously separated from the tapetum using forceps. These tissues were immediately frozen in liquid nitrogen and stored at $-70{ }^{\circ} \mathrm{C}$ before being used for RNA preparation. To assess the purity of the isolated tissues, some tissue fragments were subjected to standard histochemical analysis.

\section{Isolation and cultivation of RPE cells}

RPE cells were isolated from 1-day-old Rock Cornish chicks by the method of Hayashi et al. (1978) with some 
modifications. The membranous RPE layers were isolated as described above and processed by sequential incubation at $37{ }^{\circ} \mathrm{C}$ in the following: $0.1 \%$ trypsin (Type III; Sigma) in CMF-HSH-BSA (5 min); 0.1\% soybean trypsin inhibitor (Sigma) in CMF-HSH-BSA (10 min); 0.005\% DNase I (Sigma) in CMF-HSH-BSA (10 min). After these treatments, a single cell suspension was obtained by gentle pipetting. Cell yield was calculated by counting the cells with a hemocytometer, and cell viability was checked using a trypan blue exclusion test. The single cell suspension was collected by centrifugation, and resuspended in a culture medium of Eagle's minimum essential medium (Nissui Pharmaceutical, Tokyo, Japan) supplemented with 10\% fetal bovine serum (Gibco BRL, Grand Island, NY, USA). The resulting cells were inoculated into $9 \mathrm{~cm}$ well plates (Becton Dickinson, Lincoln Park, NJ, USA) at a cell density of $6 \times 10^{5}$ cells $/ \mathrm{ml}\left(6 \times 10^{6}\right.$ cells/well $)$, and cultured for 3 days at $37^{\circ} \mathrm{C}$ in a humidified atmosphere of $5 \%$ $\mathrm{CO}_{2}$ and $95 \%$ air.

\section{Reverse transcription (RT)-PCR analysis}

Total RNA was prepared from tissues and culture cells using the method of Chomczynski \& Sacchi (1987). One microgram of each total RNA was reverse transcribed using a SuperScript II reverse transcriptase (Gibco BRL) according to the manufacturer's directions. A one-tenth aliquot of the reactions was used in each PCR using specific primers for POMC, AGRP or MC-R subtypes (CMC1-CMC5). The primers for CMC1 were CAGGA TGGCGTTGTTGCGGTAAGT and GAATCTGCAC TCGCCCACGTACT. The sequence of other primers have been described elsewhere (for POMC, Takeuchi et al. 1999; for AGRP, Takeuchi et al. 2000; for CMC2, Takeuchi et al. 1998; for CMC3, Takeuchi \& Takahashi 1999; for CMC4 and CMC5, Takeuchi \& Takahashi 1998). The PCRs were carried out using an AmpliTaq Gold DNA polymerase (Applied Biosystems, Branchburg, NJ, USA) and a thermal cycler (Gene Amp PCR System 9600; Applied Biosystems). The conditions for the PCRs were as follows: after activation of the DNA polymerase by incubating for $9 \mathrm{~min}$ at $95^{\circ} \mathrm{C}, 42$ cycles of reactions including denaturation for $30 \mathrm{~s}$ at $95^{\circ} \mathrm{C}$ and extension for $1 \mathrm{~min}$ at $60^{\circ} \mathrm{C}$ were performed, followed by additional extension for $10 \mathrm{~min}$ at $60{ }^{\circ} \mathrm{C}$. For AGRP, the incubation temperature for extension and annealing was altered to $66{ }^{\circ} \mathrm{C}$. A one-tenth aliquot of each reaction was electrophoresed on a $2.0 \%$ agarose gel, stained with ethidium bromide, and photographed under ultraviolet illumination. The gel was subsequently transferred onto a Hybond-N+ (Amersham Pharmacia Biotech, Uppsala, Sweden) and subjected to Southern blot analysis using corresponding cDNA probes as described elsewhere (Takeuchi et al. 1996b, 1998, 1999, 2000, Takeuchi \& Takahashi 1998, 1999). Labeling and detection of the probes were carried out using an ECL Random Prime Labeling and Detection system (Amersham Pharmacia Biotech) according to the manufacturer's directions, except for the AGRP probe which was radiolabeled using $\alpha-\left[{ }^{32} \mathrm{P}\right] \mathrm{dCTP}(3000 \mathrm{Ci} /$ mmol; Amersham Pharmacia Biotech) and a Random Primer DNA Labeling Kit Version 2 (Takara, Shiga, Japan). The primers for POMC should produce 1239 and $426 \mathrm{bp}$ products from genomic and complementary DNA of the chicken POMC respectively. Similarly, primers for AGRP should produce 1521 and 426 bp products respectively. Each primer set for MC-R subtypes produces PCR products with the same size, when cDNA or genomic DNA is the template. To rule out the possibility that PCR products resulted from the amplification of genomic DNA contamination in the RNA samples, $1 \mu \mathrm{g}$ total RNA was also subjected to PCR using primers for the MC-R subtypes. The size of amplicon was 369, 567, 435, 649 and 448 bp for CMC1, CMC2, CMC3, CMC4 and CMC5 respectively.

\section{Immunocytochemistry}

One-day-old Rock Cornish chicks or embryos were killed by cervical dislocation and the eye layers dissected as described above. Pieces of the posterior cup were fixed with Bouin's solution $\left(24 \mathrm{~h}\right.$ at $\left.4{ }^{\circ} \mathrm{C}\right)$ and processed by sequential immersion: twice in $70 \%$ ethanol $\left(8 \mathrm{~h}\right.$ at $\left.4{ }^{\circ} \mathrm{C}\right)$; in $80 \%, 90 \%, 95 \%, 100 \%, 100 \%$ ethanol $(20 \mathrm{~min}$ each at $4{ }^{\circ} \mathrm{C}$ ); twice in $100 \%$ xylene ( $5 \mathrm{~min}$ at room temperature); in a 1:1 mixture of paraffin (Paraplast; Sherwood Medical, St Louis, MO, USA)-xylene $\left(10 \mathrm{~min}\right.$ at $\left.50{ }^{\circ} \mathrm{C}\right)$; in Paraplast $\left(10 \mathrm{~min}\right.$ at $50^{\circ} \mathrm{C}$ ); and embedded in Paraplast. Sections $(5 \mu \mathrm{m})$ were cut and mounted onto microscope slides. Slides bearing eye sections were deparaffinized and rehydrated by sequential immersion at room temperature: twice in xylene (15 min); in 100\%, 100\%, 90\%, 70\% ethanol (5 min each); and in distilled water (DW, $5 \mathrm{~min}$ ); and treated with $0.3 \%$ hydrogen peroxide in methanol for $10 \mathrm{~min}$ at room temperature to inhibit endogenous peroxidase activity. After being rinsed three times in DW and once in $0.01 \mathrm{M}$ phosphate-buffered saline (PBS; $0.14 \mathrm{M}$ sodium chloride in $0.01 \mathrm{M}$ sodium phosphate, $\mathrm{pH} 7 \cdot 6$ ), the slides were subjected to immunostaining using specific antisera and a Vectastain ABC kit (Vector Laboratories, Inc., Burlingame, CA, USA) according to the manufacturer's directions. The antisera used as first antisera were anti- $\alpha-$ MSH (1:2000; Biogenesis Ltd, Poole, Dorset, UK), anti-rat-ACTH (1:4000; Yanaihara Institute Inc., Shizuoka, Japan), anti-mouse-PC1/PC3 (ST-28; 1:1000) and anti-mouse-PC2 (ST-29; 1:1000). The production and characterization of the antisera against PC1/ PC3 (ST-28) and PC2 (ST-29) used in this study have been described elsewhere (Tanaka et al. 1996). The antibodies were generated in rabbits by using, as immunogens, two synthetic peptides corresponding to amino acids 442-459 (ST-28) of mouse PC1/PC3 and amino acids 613-629 (ST-29) of mouse PC2. To enhance the 
sensitivity of immunostaining for PC1 and PC2 (Tanaka et al. 1996, 1997, Kurabuchi \& Tanaka 1997), and to decolorize melanin pigments in the RPE cells, some slides were oxidized for $10 \mathrm{~s}$ at room temperature with Gomori's oxidization mixture consisting of $0.5 \%$ potassium permanganate and $0.25 \%$ sulfuric acid, bleached in 3\% sodium bisulfite for $20 \mathrm{~s}$, and then rinsed by sequential immersion at room temperature: three times in DW $(5 \mathrm{~min})$; in $0.1 \mathrm{M}$ Tris buffer, $\mathrm{pH} 8.0(5 \mathrm{~min})$; twice in DW (5 min); and in 0.01 M PBS, $\mathrm{pH} 7 \cdot 6$ (5 min) prior to being subjected to immunostaining. Non-specific immunoreactivity was blocked by incubating the slides in $2 \%$ low-fat milk (w/v) in 0.01 M PBS, $\mathrm{pH} 7 \cdot 6$ for $1 \mathrm{~h}$ at room temperature. They were then incubated with each first antiserum in $0.01 \mathrm{M}$ PBS for $24 \mathrm{~h}$ at $4{ }^{\circ} \mathrm{C}$ in a humidified box, and washed three times with 0.01 M PBS, pH 7.6. The slides were incubated with biotinylated anti-rabbit IgG in $0.01 \mathrm{M}$ PBS, pH 7.6 (1:100) for $1 \mathrm{~h}$, and then with avidin-biotinylated peroxidase complex for $30 \mathrm{~min}$ at room temperature. They were then washed three times with $0 \cdot 01 \mathrm{M}$ PBS, $\mathrm{pH} 7 \cdot 6$. Sections were immunostained in the dark for $90 \mathrm{~s}$ at room temperature in $0.02 \%$ $3,3^{\prime}$-diaminobenzidine tetrahydrochloride $(\mathrm{w} / \mathrm{v})$ solution containing $0.005 \%$ hydrogen peroxide and $0.05 \mathrm{M}$ Tris, $\mathrm{pH} 7 \cdot 6$, or two to three drops $/ 50 \mathrm{ml}$ intensifier included in the Vectastain $\mathrm{ABC}$ kit and $0.05 \mathrm{M}$ sodium phosphate, $\mathrm{pH} 7 \cdot 6$. The resulting slides were washed three times with DW for $5 \mathrm{~min}$, stained with hematoxylin for $5 \mathrm{~min}$, and then rinsed under running water for $5 \mathrm{~min}$. They were dehydrated by passage through a graded ethanol series $(70$, 90, 100 and 100\%, 5 min each) and xylene (5 min twice), mounted in paramount and cover-slipped. As negative controls, some sections were processed as above with the exception that $2 \%$ low-fat milk (w/v) was used in place of each first antiserum. For the detection of $\alpha-\mathrm{MSH}$ immunoreactivity, the primary antibody was absorbed with $10 \mu \mathrm{g} / 100 \mu \mathrm{l}$ antiserum of purified $\alpha$-MSH (Sigma) or BSA (Sigma) for $16 \mathrm{~h}$ at $4{ }^{\circ} \mathrm{C}$ before being used for immunostaining.

\section{In situ hybridization}

A 3-day-old female chick of the J-line strain of Brown Leghorns was killed by cervical dislocation. The eyes were then rapidly dissected, placed in embedding compound (Bright Cryo-M-Bed; Bright Instruments, Huntingdon, Cambs, UK) and immediately frozen in powdered dry ice. The tissue was stored at $-70{ }^{\circ} \mathrm{C}$ before being sectioned on a cryostat (Model OT; Shandon, Runcorn, Cheshire, $\mathrm{UK})$ at $15 \mu \mathrm{m}$ thickness. Sections were thaw-mounted onto microscope slides (Superfrost Plus; Cellpath, Hemel Hempstead, Herts, UK) and stored at $-70{ }^{\circ} \mathrm{C}$. Slides bearing eye sections were processed by sequential immersion at room temperature in: 4\% paraformaldehyde ( $5 \mathrm{~min})$; twice in $0 \cdot 1 \mathrm{M}$ sodium phosphate $(\mathrm{PB} ; 5 \mathrm{~min}$ each); $20 \mu \mathrm{g} / \mathrm{ml}$ proteinase $\mathrm{K}$ in $5 \mathrm{mM}$ EDTA, $10 \mathrm{mM}$
Tris buffer, pH 7.5 (7.5 min); $\mathrm{PB}$ (5 min); 4\% paraformaldehyde (5 min); PB twice (5 min each); water $(<5 \mathrm{~s})$; $0 \cdot 1 \mathrm{M}$ triethanolamine, $\mathrm{pH} 8 \cdot 0$ (TEA; $<5 \mathrm{~s}) ; 0.15 \mathrm{M}$ acetic anhydride in $0 \cdot 1 \mathrm{M}$ TEA (10 min); $2 \times$ SSC; 70\%, 95\% and $100 \%$ ethanol ( 3 min each); and blow-dried. Slides were then stored at room temperature until application of hybridization solution. The riboprobe used for in situ hybridization was generated by RT-PCR amplification of a plasmid containing chicken POMC cDNA (Takeuchi et al. 1999). Oligonucleotide primers were designed to amplify a 299 base chicken POMC cDNA fragment. Primers used were ATGCTGGGAGAACAGCAAGT GCC and GTTCCAACCCTTCTCCATCTTC, corresponding to positions 2315-2337 and 3409-3430 respectively of the chicken POMC gene (accession number $\mathrm{AB} 019555)$. The fragment was inserted into the EcoRV site of pBluescript II SK ${ }^{+}$(Stratagene, Cambridge, Cambs, UK) and transformed into E. coli XL1-Blue (Stratagene). The orientation and identity of positive clones were established by sequencing and restriction mapping. After linearization with EcoRI, a 378 base antisense chicken POMC riboprobe was transcribed from the T7 promoter of the plasmid using T7 RNA polymerase (Roche Diagnostics, Lewes, E Sussex, UK). The riboprobe was labeled with $\left[{ }^{35} \mathrm{~S} J \mathrm{UTP} \alpha \mathrm{S}\right.$ (Amersham, Little Chalfont, Bucks, UK). Hybridization solution contained chicken POMC riboprobe at approximately $2 \times 10^{6}$ d.p.m./ $100 \mu \mathrm{l}, 5 \mathrm{mg} / \mathrm{ml}$ yeast total RNA and $0.01 \mathrm{M}$ dithiothreitol (DTT) in a buffer consisting of 50\% formamide, 10\% dextran sulfate and $1 \times$ Denhardt's solution in $300 \mathrm{mM}$ $\mathrm{NaCl}, 10 \mathrm{mM}$ Tris and $1 \mathrm{mM}$ EDTA, and $100 \mu \mathrm{l}$ was applied to each slide. Slides were then cover-slipped with parafilm and incubated in a humidified chamber at $45^{\circ} \mathrm{C}$ overnight. All steps prior to and including hybridization were conducted in RNase-free conditions. Following hybridization, cover-slips were removed and slides were washed twice (15 min each) in $4 \times$ SSC and $2 \mathrm{mM}$ DTT. Slides were then placed in a pre-warmed RNase buffer consisting of $0.01 \mathrm{M}$ Tris, $\mathrm{pH} 8,0.5 \mathrm{M}$ $\mathrm{NaCl}$ and $1 \mathrm{mM}$ EDTA and containing $0.03 \mathrm{mg} / \mathrm{ml}$ RNase A. Sections were incubated for $30 \mathrm{~min}$ at $37^{\circ} \mathrm{C}$ before washing in $2 \times \mathrm{SSC}$ and $2 \mathrm{mM}$ DTT for $30 \mathrm{~min}$ at room temperature. Slides were then placed in a hot wash of $0 \cdot 1 \times$ SSC and $2 \mathrm{mM} \mathrm{DTT}$ at $55^{\circ} \mathrm{C}$ for $30 \mathrm{~min}$ and washed in $0.1 \times \mathrm{SSC}$ for $3 \mathrm{~min}$ at room temperature. Sections were dehydrated by immersion in 50\% and $85 \%$ ethanol containing $300 \mathrm{mM}$ ammonium acetate (3 min each) and a final wash in 100\% ethanol (3 min) before air-drying. Processed slides were dipped in Ilford K2 emulsion diluted 1:1 with DW, dried overnight, and exposed in the dark for 2 weeks at $4{ }^{\circ} \mathrm{C}$. Slides were then developed in D19 (Kodak) for $2.5 \mathrm{~min}$, washed for $30 \mathrm{~s}$ in DW, fixed in Ilford Hypam diluted 1:4 in DW for $3 \mathrm{~min}$, and rinsed under running water for $15 \mathrm{~min}$. Developed slides were dried, mounted in DPX and cover-slipped. 


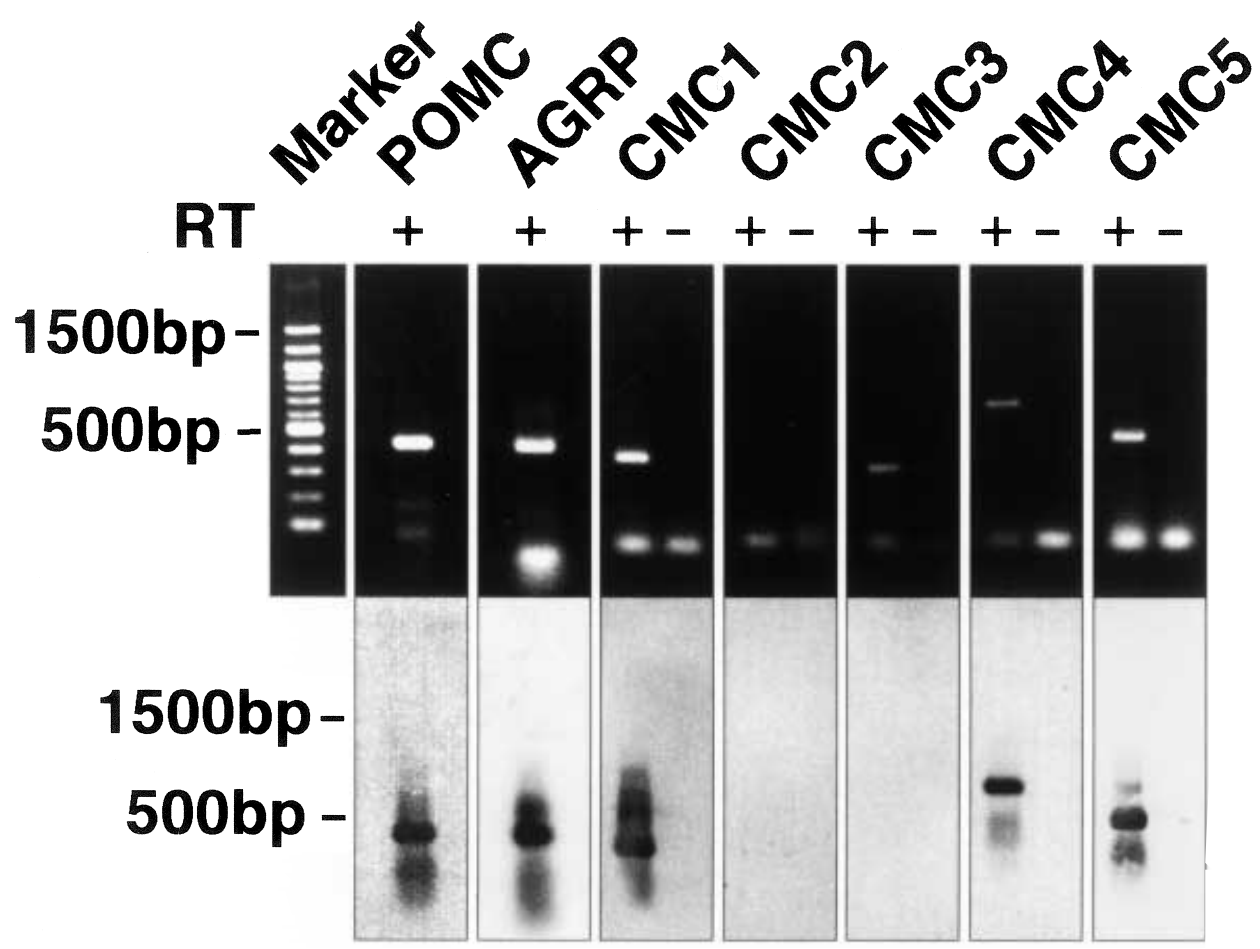

Figure 1 RT-PCR analysis of the expression of POMC, AGRP and MC-Rs mRNAs in the eye of 1-day-old Rock Cornish chicks. The upper panel shows the electrophoretic pattern of PCR products and the lower panel a Southern blot hybridization of the same gel to the chicken CDNA probes for POMC, AGRP and MC-R subtypes. A 100 bp ladder used as a molecular marker is indicated on the left. Negative controls are indicated by RT ( - ). A band observed in the CMC3 lane was revealed to be an artifact of PCR by sequence analysis.

\section{Results}

RT-PCR analysis was used to determine whether or not the melanocortin system exists in the chicken eye. As shown in Fig. 1, the eyes of 1-day-old chicks expressed mRNAs for POMC and AGRP, a common precursor of melanocortin peptides and an endogenous antagonist of MC-Rs respectively. Moreover, specific primers for MCRs produced cDNAs for CMC1, CMC4 and CMC5. These results suggest the existence of an intraocular melanocortin system in the chicken. Although ligand specificity of those MC-R subtypes remains to be determined, their mammalian orthologs respond to $\alpha-\mathrm{MSH}$ either preferentially or as well as ACTH (Cone et al. 1996, Takeuchi 1997), which led us to examine whether $\alpha-$ $\mathrm{MSH}$ is produced by the processing of POMC in the eyes.

Immunostaining was performed on eye sections of 1day-old chicks using antiserum directed against $\alpha$ MSH. As shown in Fig. 2A, the RPE cells were stained intensely. Less intense $\alpha$-MSH immunoreactivity was observed in the region between the outer limiting membrane and the RPE, particularly in some inner segments of photoreceptor cells. The immunoreactive inner segments were large in size, and their cell bodies containing nuclei were arranged in a single row immediately beneath the outer limiting membrane, the morphological characteristics of the cone cells. The $\alpha-\mathrm{MSH}$ immunoreactive cells in the photoreceptor layer are therefore presumed to be cone cells. The immunoreactivity of the RPE cells disappeared completely after preabsorption of the antiserum with $\alpha-\mathrm{MSH}$, whereas the cone cells remained stained, although staining intensity was apparently reduced (Fig. 2B). In the immunostaining with anti-ACTH antiserum or in the control, no immunoreactivity was observed (Fig. 2C and D). These results indicate that $\alpha$-MSH-like immunoreactive material exists in the RPE cells, and possibly also in the cone cells of 1-day-old chicks.

It has been reported that $\alpha$-MSH-like immunoreactive material is detectable in the cone cells and other neuronal cells in adult retinas from a variety of vertebrates including chickens (Drager et al. 1983). However, this has been assumed to result from cross-reactivity to an epitope expressed by neurofilaments because no immunoreactivity was observed when anti- $\alpha-\mathrm{MSH}$ antibodies were preabsorbed with the neurofilaments (Drager et al. 1983). 


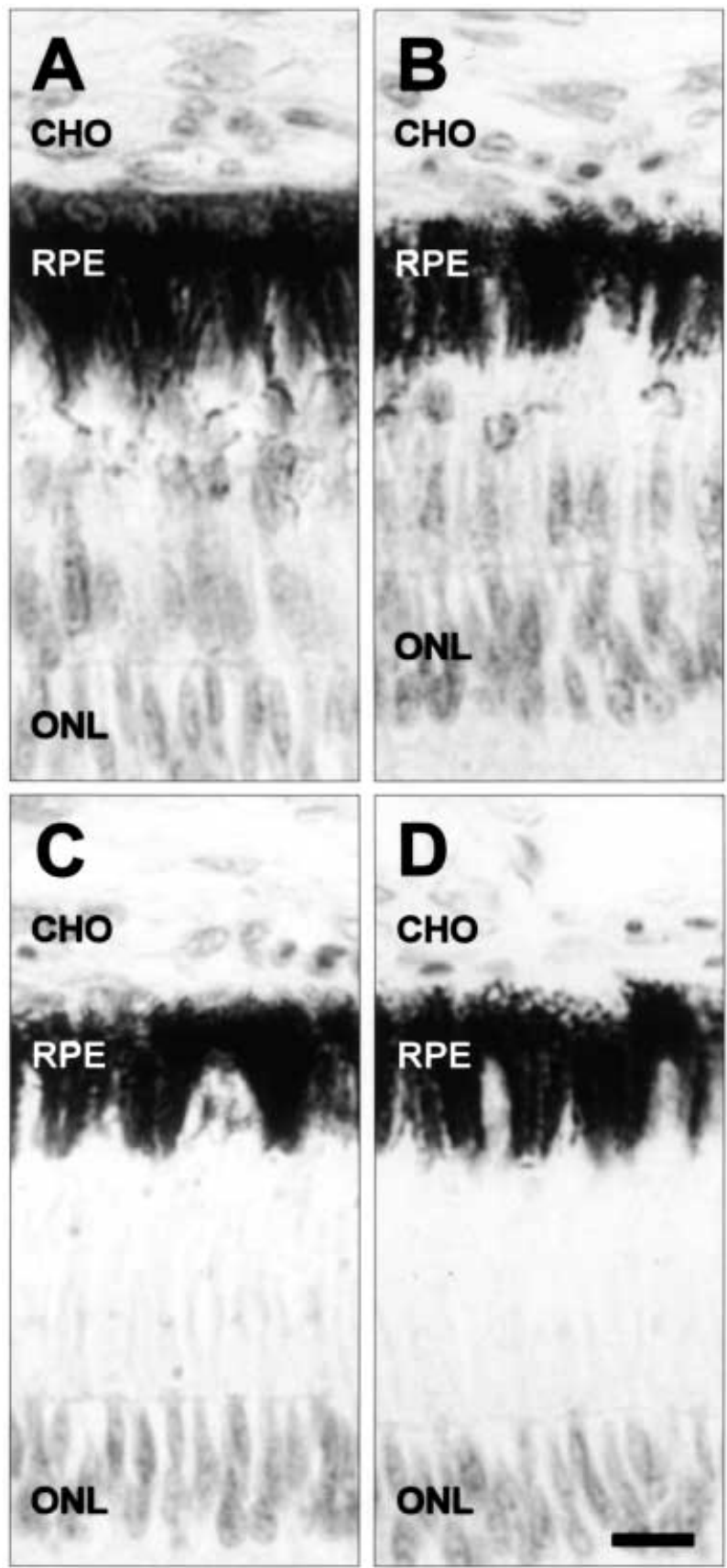

Figure 2 Immunocytochemical localization of $\alpha$-MSH in the eye of 1-day-old Rock Cornish chicks. Light micrographs are representative examples of immunostaining using anti- $\alpha-M S H$ antiserum preabsorbed with BSA (A) or $\alpha-\mathrm{MSH}$ (B) and anti-ACTH antiserum (C) as first antisera, and using low-fat milk instead of first antiserum (D; control). $\mathrm{CHO}, \mathrm{RPE}$ and $\mathrm{ONL}$ indicate layers of the choroid, retinal pigment epithelium and outer nuclear of photoreceptors respectively. Immunoreactivity is represented by half-tone staining. Scale bar $=10 \mu \mathrm{m}$.
Since the neurofilaments are widely distributed in the central nervous system (Drager et al. 1983, Trojanowski et al. 1985), it is possible that the immunoreactivity detected here represents this cross-reactivity. Furthermore, even if the immunoreactive material in the RPE cells was $\alpha-\mathrm{MSH}$, its source remains unclear since RPE cells actively take up materials from the stroma of the choroid or from the retina proper, such as vitamin A and the rod outer segments (Dowling \& Gibbon 1962). Thus, there are limitations in immunocytochemical studies for the precise localization of the sites of $\alpha-\mathrm{MSH}$ biosynthesis. To show that RPE cells express POMC at the mRNA level, RPE cells were isolated from 1-day-old chick eyes and cultured for 3 days. During the cultivation period, cells from neural retina and/or choroid disappeared so that only melanincontaining cells with an epithelial cell-like shape, the RPE cells, increased in number (data not shown). Total RNA was prepared from the RPE cells and subjected to RTPCR analysis. As expected, the cultured RPE cells did express POMC mRNA (Fig. 3A), indicating that $\alpha-\mathrm{MSH}$ is produced in the RPE cells of 1-day-old chicks.

Notably, while MC-R mRNAs were detected by RT-PCR in whole eyes, the RPE cells in primary culture did not express mRNA for any MC-R subtype. Bovine RPE cells have been suggested to express MC-Rs since $\alpha-\mathrm{MSH}$ stimulated the production of prostaglandin $\mathrm{E}_{2}$ and prostacyclin in the cells in organ culture (Ilan et al. 1992). It is possible that the chicken RPE cells do express the MC-Rs, and their expression was repressed due to the cells being isolated and cultured for 3 days. To address this possibility, an attempt was made to isolate individual cell layers of the RPE, choroid and neural retina from 1-dayold chicks. The RT-PCR analysis of RNAs from those layers revealed that all $\mathrm{MC}-\mathrm{R}$ subtypes detected in whole eyes, CMC1, CMC4 and CMC5, were expressed in the layers of the choroid and the neural retina, but not in the RPE (Fig. 3B-D). These results not only indicate that the chicken RPE cells do not express the MC-Rs in vivo and in vitro, but also suggest that $\alpha-\mathrm{MSH}$ produced in the RPE cells affects the adjacent layers, the choroid and the neural retina in a paracrine fashion.

The POMC mRNA expression was observed in the layer of the neural retina as well as in the RPE cells. It is possible that the $\alpha-\mathrm{MSH}$ immunoreactivity detected in the cone cells could be $\alpha-\mathrm{MSH}$ produced in the cells themselves. A faint band of POMC cDNA was also detectable in the choroid (Fig. 3D), which might result from contamination with RPE cells since histochemical observation of the isolated choroid tissues revealed that small amounts of RPE cells remained attached to the choroid layers (data not shown). Similar analyses were performed to localize AGRP expression, and showed that all eye layers and the cultured RPE cells express AGRP mRNA (Fig. 4).

In adult chickens, as mentioned above, immunoreactive $\alpha-\mathrm{MSH}$ has been localized to the cone cells and other 


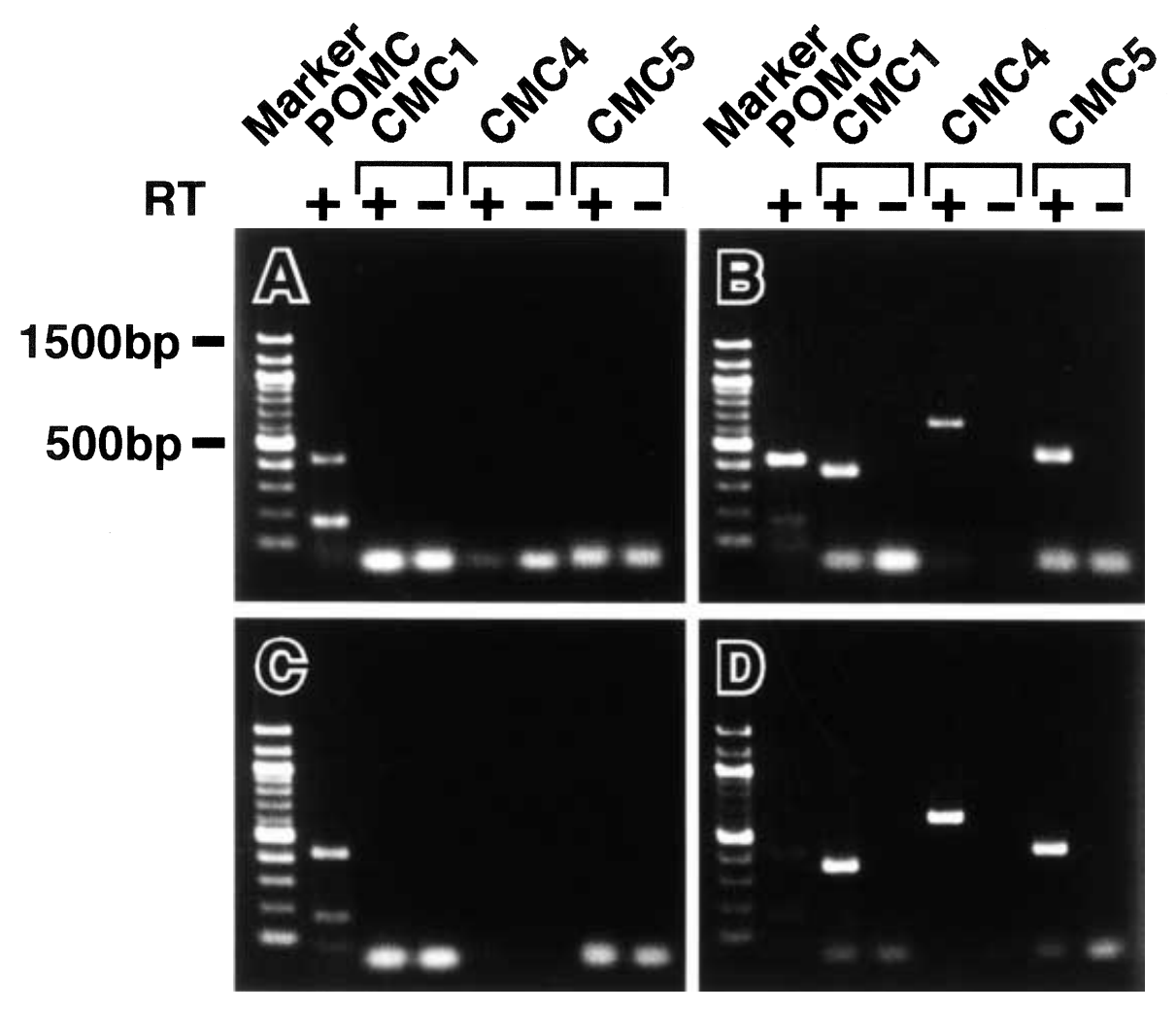

Figure 3 RT-PCR analysis of the expression of mRNAs for POMC and some MC-R subtypes in RPE cells in culture and in eye layers of 1-day-old Rock Cornish chicks. The electrophoretic pattern of PCR reactions amplifying CDNAs from the RPE cells in primary culture (A) and from individual cell layers of the neural retina (B), RPE (C) and choroid (D) is shown. In each case, a 100 bp ladder used as a molecular marker is indicated on the left. Negative controls are indicated by RT ( -$)$.

neuronal cells in the retina, but not in the RPE cells (Drager et al. 1983). On the other hand, in 1-day-old chicks, $\alpha-\mathrm{MSH}$ was predominantly produced in the RPE cells, and the cone cells expressed relatively small amounts of $\alpha$-MSH immunoreactivity. The difference between chicks and adult chickens in localization of $\alpha-\mathrm{MSH}$ (or immunoreactive $\alpha-\mathrm{MSH}$ ) led us to speculate that the expression pattern of $\alpha-\mathrm{MSH}$ in the eye changes during development or growth in the chicken.

To address this possibility, we compared the expression of $\alpha-\mathrm{MSH}$ in the eyes between chicken embryos at different developmental stages and in 1-day-old chicks by immunocytochemistry (Fig. 5). In the embryonic stages tested (embryonic days 7, 10, 13 and 17), $\alpha-\mathrm{MSH}$ immunoreactivity was initially detected in the RPE cells at embryonic day 10, and the staining intensity increased as embryonic development proceeded. The RPE cells of 1-day-old chicks expressed relatively low levels of immunoreactivity compared with those of embryos at 17 days of incubation, and no photoreceptor cells were stained with anti- $\alpha-\mathrm{MSH}$ antiserum in any of the embryonic stages tested. The occurrence of $\alpha-\mathrm{MSH}$ expression in the RPE cells was further confirmed by demonstrating that the prohormone convertases PC1 and PC2 immunoreactivities were co-localized to the RPE cells, and their expression levels correlated well with that of $\alpha-\mathrm{MSH}$ as assessed by the intensity of the immunostaining. No immunoreactivity was detected with anti-ACTH antiserum. The RPE cells of 1-day-old chicks contained immunoreactivity for $\alpha-\mathrm{MSH}$, but not for the endoproteases, suggesting that the production of $\alpha-\mathrm{MSH}$ in the RPE cells ceases after hatching.

Further evidence for the change in localization of $\alpha-\mathrm{MSH}$ expression after hatching is provided by the observation that POMC mRNA was detectable only in some cells in the photoreceptor layer, and no positive signal was observed in the RPE cells (Fig. 6). This result, together with our observations in the 1-day-old chick that the level of $\alpha-\mathrm{MSH}$ immunoreactivity was lower in the neural retina than in the RPE cells, suggest that it is probable that the production of $\alpha-\mathrm{MSH}$ in the RPE cells is extensive during middle to late embryonic development and ceases after hatching and that, in contrast, the cone cells express $\alpha$-MSH postnatally. 


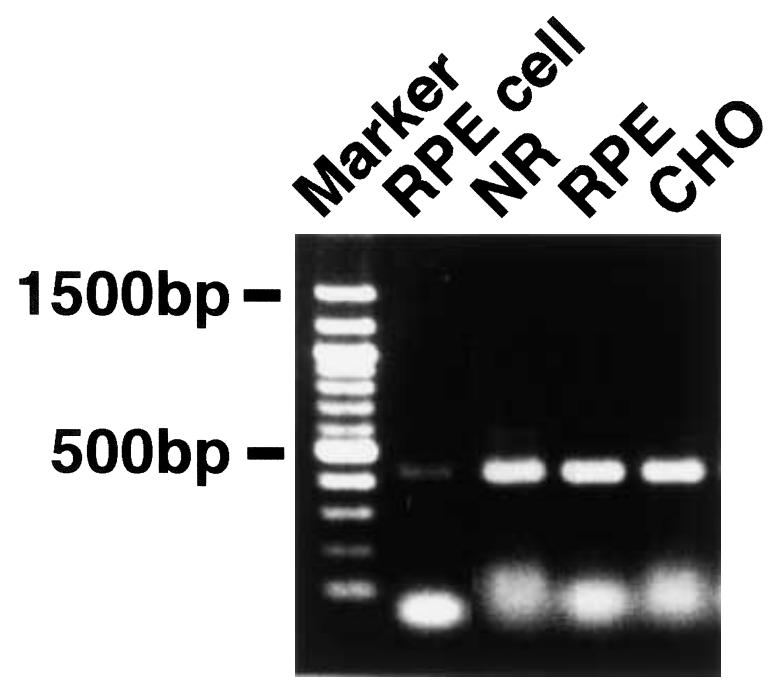

Figure 4 RT-PCR analysis of the expression of AGRP mRNA in RPE cells in culture and in eye layers of 1 -day-old Rock Cornish chicks. The electrophoretic pattern of each PCR reaction using cDNA from the RPE cells in primary culture (RPE cell) and from individual cell layers of the neural retina (NR), RPE and choroid $(\mathrm{CHO})$ is shown. A $100 \mathrm{bp}$ ladder used as a molecular marker is indicated on the left.

\section{Discussion}

The present study was undertaken to determine whether $\alpha-\mathrm{MSH}$ is produced in the chicken eye. A combination of immunocytochemistry and RT-PCR provided evidence for $\alpha-\mathrm{MSH}$ expression in the RPE cells, and also at a lower level in the cone cells of 1-day-old chicks. Since its receptors, CMC1, CMC4 and CMC5, were expressed in the layers of the choroid and the neural retina, adjacent to the RPE cells, it is probable that the RPE cells secrete $\alpha-\mathrm{MSH}$ to exert paracrine effects on those layers. $\alpha-\mathrm{MSH}$ expressed in the cone cells, on the other hand, might be acting as a neurotransmitter or neuromodulator in the neural retina. The expression of AGRP was also detected in the eyes. It remains unclear at present, however, whether AGRP is involved in this intraocular $\alpha-\mathrm{MSH}$ system since its expression did not show a cell type specificity. As we suggested previously (Takeuchi et al. 2000), the AGRP gene might be expressed ubiquitously at low levels in the chicken. Alternatively, the AGRP expression pattern observed might result from an unusual mutation analogous to the $A^{\mathrm{y}}$ agouti allele in mice (Bultman et al. 1992), and the expression pattern may vary among different chicken breeds. From this point of view, it would be of great interest to examine the cellular distribution of AGRP expression in the chicken brain, as AGRP in mammals is expressed mainly in the arcuate nucleus where it plays an important role in the hypothalamic control of feeding and energy homeostasis by antagonism of central melanocortin 4 receptors (Ollmann et al. 1997, Shutter et al. 1997).

In the present study, immunocytochemistry and in situ hybridization revealed temporal and spatial patterns of $\alpha-\mathrm{MSH}$ expression in the eye during development of the chicken. The expression of $\alpha-\mathrm{MSH}$ was initially detected in the RPE cells at embryonic day 10, and its level increased as embryonic development proceeded. After hatching, the production of $\alpha-\mathrm{MSH}$ probably ceased since the RPE cells in 1-day-old chicks did not contain either of the two endoproteases involved in $\alpha-\mathrm{MSH}$ generation from POMC, and POMC mRNA could not be detected in the RPE cells of 3-day-old chicks by in situ hybridization. On the other hand, expression of $\alpha-\mathrm{MSH}$ or POMC was observed in the cone cells only after hatching (1- and 3 -day-old chicks in the present study) and possibly in adults in an earlier report (Drager et al. 1983). Although detailed temporal and spatial localization of $\alpha-\mathrm{MSH}$ expression is required, it is probable that the RPE and cone cells produce embryonic and postnatal $\alpha-\mathrm{MSH}$ respectively. Many lines of evidence have shown that proliferation, differentiation and apoptosis of retinal cells during ocular development are humorally regulated by growth factors generated within the eye, such as fibroblast growth factors (Guillemot \& Cepko 1992, Consigli et al. 1993, Tcheng et al. 1994, Pittack et al. 1997, Yokoyama et al. 1997, Desire et al. 1998) and insulin-like growth factors (de La Rosa et al. 1994, Hernandez-Sanchez et al. 1995, Calvaruso et al. 1996), by an autocrine and/or paracrine mechanism. The expression pattern in the RPE cells suggests a possible involvement of $\alpha-\mathrm{MSH}$ in regulating the embryonic development of the chicken eye in a similar fashion. However, the exact physiological role of $\alpha-\mathrm{MSH}$ during ocular development remains to be elucidated. It is unclear at present whether the intraocular $\alpha-\mathrm{MSH}$ system exists in other vertebrates. Similar analyses on mouse eyes are now in progress. Further analysis of the ocular $\alpha$-MSH system will contribute to our understanding of how eye development is regulated by $\alpha-\mathrm{MSH}$, and provide a foundation for future attempts to develop methods of treatment for eye diseases in which melanocortin peptides may be the causative agents, such as the central serous retinopathy linked to the therapeutic use of ACTH or to endogenous ACTH hypersecretion (Zamir 1997).

$\alpha$-MSH was discovered 90 years ago as a potent stimulator of pigment cells, modulating color change in amphibia (Eberle 1988). Surgical ablation of the intermediate lobe of the pituitary results in frogs turning pale, giving rise to the idea that the gland plays a key role in $\alpha-\mathrm{MSH}$ function. The absence of this region in the avian pituitary has led to the general thought that $\alpha-\mathrm{MSH}$ is a hormone of negligible interest with no physiological roles in birds. Up to now, neither the occurrence nor a physiological role for $\alpha-\mathrm{MSH}$ has been established in birds. In mammals, $\alpha-\mathrm{MSH}$ exerts a multiplicity of effects 

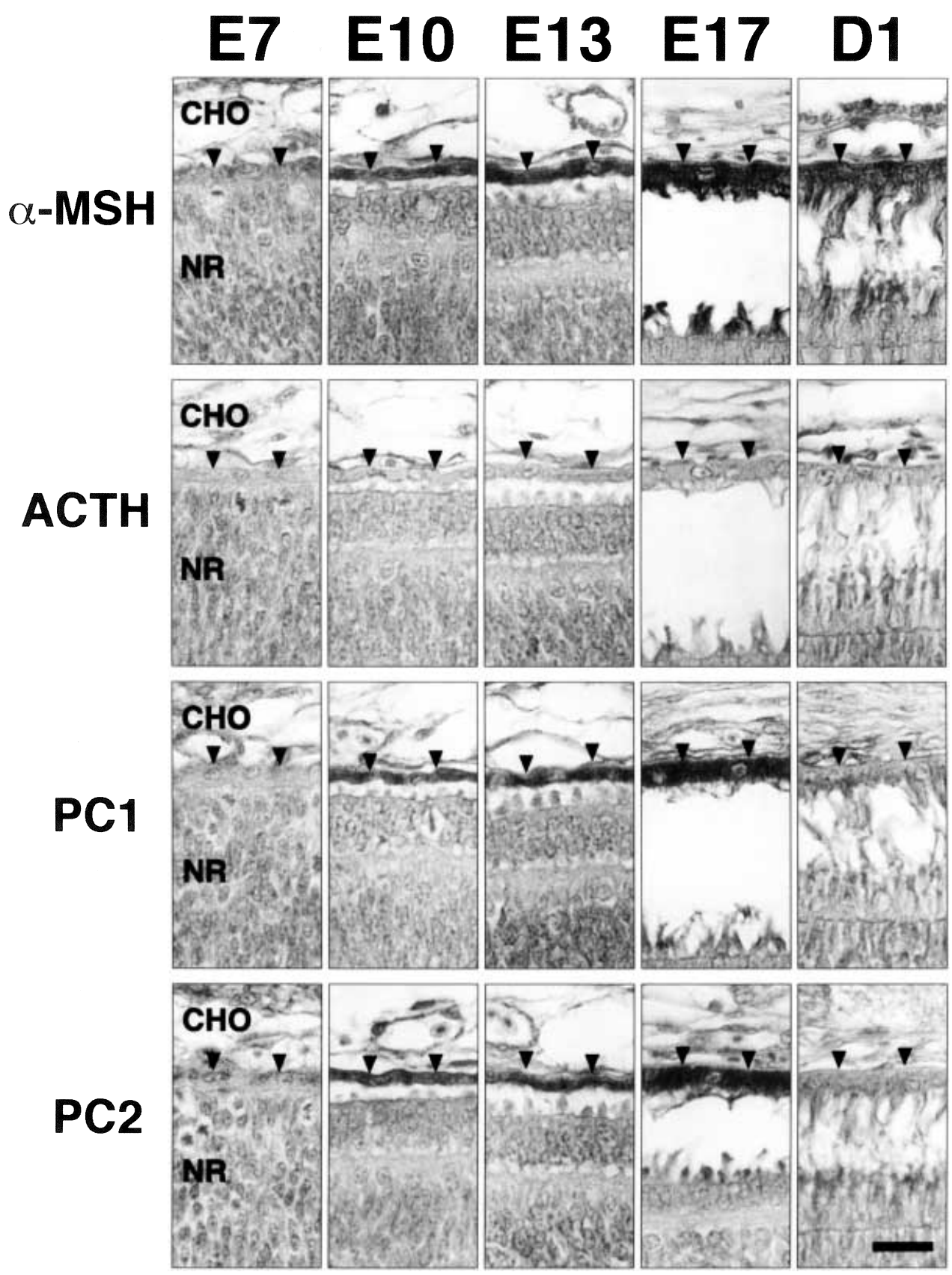

Figure 5 Immunostaining for $\alpha-\mathrm{MSH}, \mathrm{ACTH}$ and PC1 and PC2 in the eye of Rock Cornish chicken at different developmental stages. Light micrographs are representative examples of immunostaining using anti- $\alpha$-MSH antiserum preabsorbed with BSA, anti-ACTH antiserum, and antisera directed against the two prohormone convertases, PC1 and PC2, as first antisera. Developmental stages are indicated on the top of each set of panels; E7-E17 and D1 indicate embryonic days 7-17 and day 1 after hatching respectively. Sections were oxidized with Gomori's oxidization mixture prior to immunostaining to enhance the sensitivity of immunostaining for PC1 and PC2, and to decolorize melanin pigments in the RPE cells. In most sections, an artifactitious separation is found between the photoreceptor layer and the RPE, which is a fixation artifact due to lack of actual anatomical connection between the two layers. The retinal pigment epithelium is indicated by arrowheads. $\mathrm{CHO}$ and NR indicate layers of the choroid and neural retina respectively. Scale bar $=20 \mu \mathrm{m}$. 


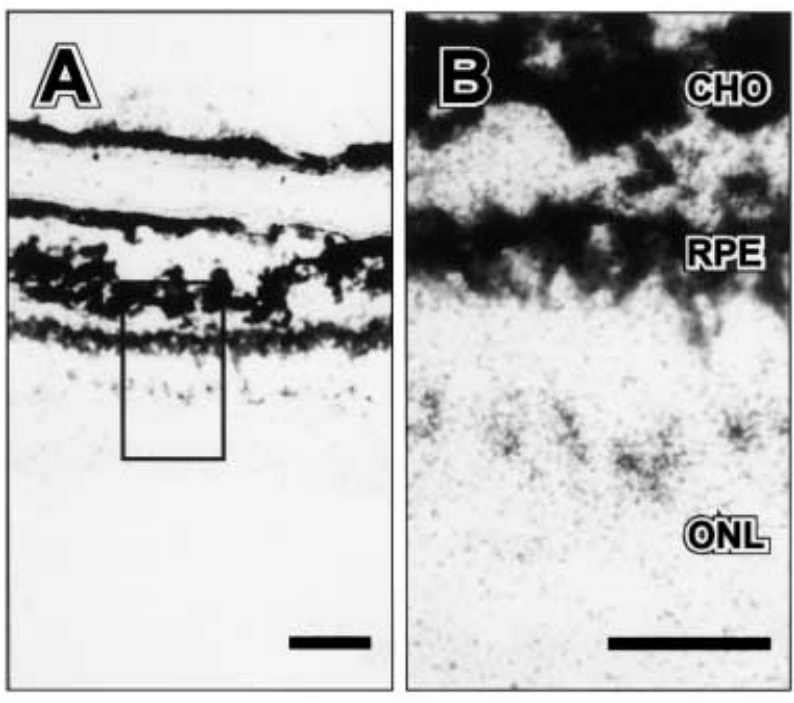

Figure 6 Localization of POMC mRNA by in situ hybridization in the eye of a 3-day-old Brown Leghorn chick. Light micrographs at lower $(\times 20)(A)$ and high $(\times 80)(B)$ magnification are presented. Positive signals (densely clustered silver grains) are arranged in a single row in the photoreceptor layer. The choroid $(\mathrm{CHO}), \mathrm{RPE}$ and outer nuclear layer (ONL) are labeled. Scale bars are $20 \mu \mathrm{m}$ (A) and $40 \mu \mathrm{m}(\mathrm{B})$.

throughout the body where it acts as a neuroendocrine, paracrine and autocrine local hormone. To obtain insight into the evolution of the $\alpha-\mathrm{MSH}$ endocrine system, we have cloned the chicken POMC and AGRP genes, and those of all five MC-R subtypes. Our analyses of the tissue distribution of expression of these genes have revealed their widespread expression throughout the body of the chicken (Takeuchi et al. 1996a, 1998, 1999, 2000, Takeuchi \& Takahashi 1998, 1999), raising the possibility that the physiological role of $\alpha-\mathrm{MSH}$ has been conserved during evolution so that it acts as a paracrine and/or autocrine hormone in birds as it does in mammals. Besides birds, some mammalian species, including humans, also lack the intermediate lobe of the pituitary (Eberle 1988). Based on these observations, we have proposed the hypothesis that most of the functions assigned to $\alpha-\mathrm{MSH}$ in higher vertebrates may be modulated by locally produced $\alpha-\mathrm{MSH}$ via paracrine and/or autocrine mechanisms in vivo. The intermediate lobe of the pituitary may have developed as the primary secretory gland of circulating $\alpha-\mathrm{MSH}$ involved in physiological color change in lower vertebrates, and the main physiological roles of the gland might have altered during evolution towards animals bearing feather or hair. $\alpha-\mathrm{MSH}$ may be essentially a paracrine and/or autocrine hormone (Takeuchi et al. 1999, 2000). The present study provides the first evidence for $\alpha-\mathrm{MSH}$ expression in peripheral tissues in birds, and sets the scene for investigation into paracrine and/or autocrine effects of the hormone.
In conclusion, the present study demonstrates for the first time that $\alpha-\mathrm{MSH}$ is expressed within the chicken eye, and that its intraocular expression is temporally and spatially regulated during development. Embryonic expression of $\alpha-\mathrm{MSH}$ in the RPE cells suggests its role in the development of the eye. This is the first report demonstrating the expression of $\alpha-\mathrm{MSH}$ in peripheral tissues in birds, and supports our hypothesis that avian $\alpha-\mathrm{MSH}$ is a paracrine/autocrine hormone.

\section{Acknowledgements}

This work was supported in part by a Grant-in Aid for Scientific Research (No. 12640650) from the Japan Society for the Promotion of Science to S T.

\section{References}

Bauer B \& Ehinger B 1980 Action of $\alpha-\mathrm{MSH}$ on the release of neurotransmitters from the retina. Acta Physiologica Scandinavica 108 105-107.

Bauer B, Ehinger B \& Aberg L $1980\left[{ }^{3} \mathrm{H}\right]$-dopamine release from the rabbit retina. Albrecht Von Graefes Archiv für Klinische und Experimentelle Ophthalmologie 215 71-78.

Benjannet S, Rondeau N, Day R, Chretien M \& Seidah NG 1991 $\mathrm{PC} 1$ and PC2 are proprotein convertases capable of cleaving proopiomelanocortin at distinct pairs of basic residues. PNAS $\mathbf{8 8}$ 3564-3568.

Bultman SJ, Michaud EJ \& Woychik RP 1992 Molecular characterization of the mouse agouti locus. Cell 71 1195-1204

Calvaruso G, Vento R, Guiliano M, Lauricella M, Gerbino E \& Tesoriere G 1996 Insulin-like growth factors in chick embryo retina during development. Regulatory Peptides 61 19-25.

Chomczynski P \& Sacchi N 1987 Single step method of RNA isolation by acid guanidinium thiocyanate-phenol-chloroform extraction. Analytical Biochemistry 162 156-159.

Cone RD, Lu D, Koppula S, Vage DI, Klungland H, Boston B, Chen W, Orth DN, Pouton C \& Kesterson RA 1996 The melanocortin receptors: agonists, antagonists, and the hormonal control of pigmentation. Recent Progress in Hormone Research 51 287-318.

Consigli SA, Lyser KM \& Joseph-Silverstein J 1993 The temporal and spatial expression of basic fibroblast growth factor during ocular development in the chicken. Investigative Ophthalmology and Visual Science 34 559-566.

Desire L, Head MW, Fayein NA, Courtois Y \& Jeanny JC 1998 Suppression of fibroblast growth factor 2 expression by antisense oligonucleotides inhibits embryonic chick neural retina cell differentiation and survival in vivo. Developmental Dynamics 212 63-74.

Dowling JE \& Gibbon LR 1962 The fine structure of the pigment epithelium in the albino rat. Journal of Cell Biology 14 459-474.

Drager UC, Edwards DS \& Kleinschmidt J 1983 Neurofilaments contain alpha-melanocyte-stimulating hormone $(\alpha-\mathrm{MSH})$-like immunoreactivity. PNAS 80 6408-6412.

Dyster-Aas HK \& Krakau CET 1964 Increased permeability of the blood-aqueous humor barrier in the rabbit's eye provoked by melanocyte stimulating peptides. Endocrinology 74 255-265.

Dyster-Aas HK, Kastin AJ, Vidacovich RP \& Schally AV 1970 Melanocyte-stimulating activity in serum and the aqueous flare response in rabbits. Journal of Endocrinology 46 285-286.

Eberle AN 1988 The Melanotropins: Chemistry, and Mechanisms of Action. Basel: Karger. 
Guillemot F \& Cepko CL 1992 Retinal fate and ganglion cell differentiation are potentiated by acidic FGF in an in vitro assay of early retinal development. Development 144 743-754.

Hanaoka T 1951 Effect of melanophore hormone upon the scotopic vision of human eye. Japanese Journal of Physiology 2 9-16.

Hanaoka T 1953 Effect of melanophore hormone on regeneration of visual purple in solution. Nature 172866.

Hayashi M, Asayama K \& Ueno S 1978 Tissue culture of the retinal pigment epithelial cells. Acta Ophthalmologica 56 83-94.

Hernandez-Sanchez C, Lopez-Carranza A, Alarcon C, de La Rosa EJ \& de Pablo F 1995 Autocrine/paracrine role of insulin-related growth factors in neurogenesis: local expression and effects on cell proliferation and differentiation in retina. PNAS 92 9834-9838.

Ilan AB, Savion N \& Naveh N 1992 Alpha melanocyte stimulating hormone $(\alpha-\mathrm{MSH})$ enhances eicosanoid production by bovine retinal pigment epithelium. Prostaglandins 43 31-44.

Korner J, Chun J, Harter D \& Axel R 1991 Isolation and functional expression of a mammalian prohormone processing enzyme, murine prohormone convertase 1. PNAS 88 6834-6838.

Kurabuchi S \& Tanaka S 1997 Immunocytochemical localization of prohormone convertase PC1 and PC2 in the anuran pituitary gland: subcellular localization in corticotrope and melanotrope cells. Cell and Tissue Research 288 485-496.

Kwon HY, Bultman SJ, Loffler C, Chen WJ, Furdon PJ, Powell JG, Usala AL, Wilkison W, Hansmann I \& Woychik RP 1994 Molecular structure and chromosomal mapping of the human homolog of the agouti gene. PNAS 91 9760-9764.

de La Rosa EJ, Bondy CA, Hernandez-Sanchez C, Wu X, Zhou J, Lopez-Carranza A, Scavo LM \& de Pablo F 1994 Insulin and insulin-like growth factor system components gene expression in the chicken retina from early neurogenesis until late development and their effect on neuroepithelial cells. European Journal of Neuroscience 6 1801-1810.

Lu D, Willard D, Patel IR, Kadwell S, Overton L, Kost T, Luther M, Chen W, Woychik RP, Wilkison WO \& Cone RD 1994 Agouti protein is an antagonist of the melanocyte-stimulating-hormone receptor. Nature 371 799-802.

Mains RE \& Eipper BA 1990 The tissue-specific processing of pro-ACTH/endorphin: recent advances and unsolved problems. Trends in Endocrinology and Metabolism 1 388-394.

Ollmann MM, Wilson BD, Yang YK, Kerns JA, Chen Y, Gantz I \& Barsh GS 1997 Antagonism of central melanocortin receptors in vitro and in vivo by agouti-related protein. Science 278 135-138.

Pittack C, Grunwald GB \& Reh TA 1997 Fibroblast growth factors are necessary for retina but not pigmented epithelium differentiation in chick embryos. Development 124 805-816.

Shutter JR, Graham M, Kinsey AC, Scully S, Luthy R \& Stark KL 1997 Hypothalamic expression of ART, a novel gene related to agouti, is up-regulated in obese and diabetic mutant mice. Genes and Development 11 593-602.

Smith AI \& Funder JW 1988 Proopiomelanocortin processing in the pituitary, central nervous system, and peripheral tissues. Endocrine Reviews 9 159-179.

Takeuchi S 1997 Melanocortin receptors. Seitai no Kagaku 48 426-429 (in Japanese).

Takeuchi S \& Takahashi S 1998 Melanocortin receptor genes in the chicken - tissue distributions. General and Comparative Endocrinology 112 220-231.
Takeuchi S \& Takahashi S 1999 A possible involvement of melanocortin 3 receptor in the regulation of adrenal gland function in the chicken. Biochimica et Biophysica Acta 1448 512-518.

Takeuchi S, Suzuki H, Hirose S, Yabuuchi M, Sato C, Yamamoto H \& Takahashi S 1996a Molecular cloning and sequence analysis of the chick melanocortin 1-receptor gene. Biochimica et Biophysica Acta 1306 122-126.

Takeuchi S, Suzuki H, Yabuuchi M \& Takahashi S 1996b A possible involvement of melanocortin 1-receptor in regulating feather color pigmentation in the chicken. Biochimica et Biophysica Acta 1308 164-168.

Takeuchi S, Kudo T \& Takahashi S 1998 Molecular cloning of the chicken melanocortin 2 (ACTH)-receptor gene. Biochimica et Biophysica Acta 1403 102-108.

Takeuchi S, Teshigawara K \& Takahashi S 1999 Molecular cloning and characterization of the chicken pro-opiomelanocortin (POMC) gene. Biochimica et Biophysica Acta 1450 452-459.

Takeuchi S, Teshigawara K \& Takahashi S 2000 Widespread expression of Agouti-related protein (AGRP) in the chicken: a possible involvement of AGRP in regulating peripheral melanocortin systems in the chicken. Biochimica et Biophysica Acta $1496261-269$.

Tanaka S, Kurabuchi S, Mochida H, Kato T, Takahashi S, Watanabe T \& Nakayama K 1996 Immunocytochemical localization of prohormone convertases $\mathrm{PC} 1 / \mathrm{PC} 3$ and $\mathrm{PC} 2$ in rat pancreatic islets. Archives of Histology and Cytology 59 261-271.

Tanaka S, Yora T, Nakayama K, Inoue K \& Kurosumi K 1997 Proteolytic processing of pro-opiomelanocortin occurs in acidifying secretory granules of AtT-20 cells. Journal of Histochemistry and Cytochemistry 45 425-436.

Tcheng M, Oliver L, Courtois Y \& Jeanny JC 1994 Effects of exogenous FGFs on growth, differentiation, and survival of chick neural retina cells. Experimental Cell Research 212 30-35.

Thomas L, Leduc R, Thorne BA, Smeekens SP, Steiner DF \& Thomas G 1991 Kex2-like endoproteases PC2 and PC3 accurately cleave a model prohormone in mammalian cells: evidence for a common core of neuroendocrine processing enzymes. PNAS $\mathbf{8 8}$ $5297-5301$.

Trojanowski JQ, Stone RA \& Lee VM 1985 Presence of an alphamelanocyte-stimulating hormone-like epitope in the 150000 dalton neurofilament subunit from diverse regions of the central nervous system: an immunohistochemical and immunoblot study in guinea pig. Journal of Histochemistry and Cytochemistry 33 900-904.

Wilson BD, Ollmann MM, Kang L, Stoffel M, Bell GI \& Barsh GS 1995 Structure and function of ASP, the human homolog of the mouse agouti gene. Human Molecular Genetics 4 223-230.

Yokoyama Y, Ozawa S, Seyama Y, Namiki H, Hayashi Y, Kaji K, Shirama K, Shioda M \& Kano K 1997 Enhancement of apoptosis in developing chick neural retina cells by basic fibroblast growth factor. Journal of Neurochemistry 68 2212-2215.

Zamir E 1997 Central serous retinopathy associated with adrenocorticotrophic hormone therapy. A case report and a hypothesis. Albrecht Von Graefes Archiv für Klinische und Experimentelle Ophthalmologie 235 339-344.

Received 7 September 2000

Accepted 22 November 2000 